IJMPB

14,6

1270

Received 13 August 2020

Revised 8 February 2021

Accepted 16 March 2021

\section{Organizational culture and project management methodology: research in the financial industry}

\author{
Katarzyna Piwowar-Sulej \\ Department of Labor, Capital and Innovation, Wroclaw University of Economics, \\ Wroctaw, Poland
}

\begin{abstract}
Purpose - Organizational culture has an impact on various activities in organizations, including project management (PM). The aim of the study is to answer the following research questions: RQ1: what significance is attributed to organizational culture compared to the objective project characteristics when choosing the dominant PM methodology in organizations? RQ2: which type of organizational culture is preferred for successful implementation of different PM methodologies? RQ3: what kind (if any) of relationship exists between the dominant type of organizational culture in organizations and the dominant PM methodology?

Design/methodology/approach - The author surveyed 100 project managers working in the financial industry in Poland with the use of personal structured interviews. The competing values framework (CVF) concept authored by Cameron and Quinn was used.

Findings - Project managers find organizational culture more important than objective project characteristics when choosing the dominant PM methodology in an organization. Although statistical analysis revealed a significant relationship between the preferred type of organizational culture and PM methodology, there is no significant relationship between the existing type of organizational culture and the PM methodology which prevails in the company.

Research limitations/implications - Future research should investigate other industries and other typologies of organizational culture.

Practical implications - The paper provides recommendations for management practice on how to shape organizational culture in the context of successful PM with the application of different PM methodologies.

Originality/value - This study fills a gap in the theory of PM by identifying and empirically verifying the theoretical linkage between the type of organizational culture and PM methodology.
\end{abstract}

Keywords Human resource management, Agile, Management approach, Corporate culture, Project success, Organizational behavior, Project competencies, People in project-based organizations

Paper type Research paper

\section{Introduction}

The interest of researchers and practitioners in intangible management factors increased in the 1980s. Other types of noneconomic reasons which can affect the success or failure of an enterprise were investigated (Webster and Jensen, 2006). Among these factors, organizational culture was of particular interest (Alvesson, 1990).

Organizational culture represents the collection of beliefs, values, norms, attitudes and assumptions which dominate in a company and which do not have to be formulated. This set of elements influences people's behavior and the accomplishment of their tasks (Schein, 1990). The culture which connects people in an organization remains very closely linked to the

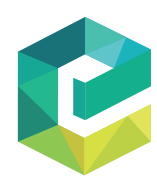

International Journal of Managing Projects in Business Vol. 14 No. 6,2021 pp. $1270-1289$ Emerald Publishing Limited 1753-8378 DOI 10.1108/IJMPB-08-2020-0252

(C) Katarzyna Piwowar-Sulej. Published by Emerald Publishing Limited. This article is published under the Creative Commons Attribution (CC BY 4.0) licence. Anyone may reproduce, distribute, translate and create derivative works of this article (for both commercial and non-commercial purposes), subject to full attribution to the original publication and authors. The full terms of this licence may be seen at http:// creativecommons.org/licences/by/4.0/legalcode

The project is financed by the Ministry of Science and Higher Education in Poland under the program "Regional Initiative of Excellence" 2019-2022 project number 015/RID/2018/19 total funding amount 10,721,040.00 PLN. 
organization's performance (Denison and Mishra, 1995; Martins and Terblanche, 2003; Mathew, 2007; Lucas, 2006; Hartog and Verburg, 2004). This is the key factor in fulfilling the company's mission and implementing its strategy while improving organizational efficiency culture and managing transformations.

Radical changes in the functioning of organizations have occurred within the last few decades. The increasingly uncertain and competitive environment and the growing expectations of customers and employees have forced companies to introduce changes. Repetitive, routine operations are gradually losing importance in favor of unique and complex activities - i.e. projects (Piwowar-Sulej, 2020). In the 1990s, Drucker wrote that in 20 years, a typical large company would have half as many managerial levels and particular tasks would be performed by specialists focused on specific projects, functioning alongside traditional departments (Drucker, 1992). Today, even in those industries where traditionally repetitive activities have been the basis of their operations, projects are beginning to play an increasingly important role.

One example of such an organization is a financial company. Every day, the main processes related to sales, e.g. loans and after-sales service, are carried out. Ancillary processes include administrative activities. The purpose of subsequent projects is, e.g. to open a new branch, to launch a new product or to develop an advertising campaign. Project initiation in organizations based on traditional structures involves the need to mobilize resources which belong to multiple organizational units, for the objectives to be carried out in a specific time frame and to be managed by project managers. An employee frequently performs a dual role: as a specialist in his/her line department and as a project team member.

A project can be defined as an "endeavor in which human, material, and financial resources are organized in an innovative way to carry out an extraordinary scope of work, in line with the defined specifications, within cost and time constraints, to achieve a positive change determined by quantitative and qualitative goals" (Turner, 1993, p. 8). Project management (PM), in turn, is the "application of knowledge, skills, tools, and techniques in relation to project activities in order to meet or exceed the needs and expectations of stakeholders associated with the project" (Ward, 2000, p. 468).

Projects can be managed in accordance with guidelines presented in PM methodologies. These methodologies are referred to as guides to the types of documentation and eligibilities necessary to complete particular project stages. The literature on the subject offers two general approaches toward running projects: traditional (managerial) and modern (agile, adaptive, dynamic or light). The traditional approach has its roots in the 1950s, while the modern one is from the 1990s. Traditional methodologies describe major processes and present, in a systematized way, a set of verified management techniques. Moreover, they imply that each stage of the project can only be initiated when the previous one has been fully completed. They also stress the completeness of documentation. Such an approach has become insufficient over the years, especially for software development projects (Berger and Beynon-Davies, 2009). In the agile approach, the actions are adapted on an ongoing basis. The differences between these two approaches to PM should be also expressed in organizational culture because one of the main causes of project failure presented in the literature on the subject is that the organizational culture in which projects have to be delivered is not suitable for projects (Larson and Gray, 2011).

The aim of the study is to present the significance of organizational culture as a factor which determines the choice of PM methodologies and the relationships between the two. In the first section of the paper, previous research in the literature on the linkages between organizational culture and PM issues is presented. This was the basis of the research questions. The second section, i.e. the empirical part of the paper, presents original research with its methodology, results and discussion. The paper ends with conclusions, limitations and directions for further research. It contributes to the scientific knowledge by (1) identifying and describing the linkages between the type of organizational culture and the type of PM methodology, (2) verifying the assumption through original research findings and (3) presenting directions for future research. 
IJMPB 14,6

\section{Literature background}

\section{Organizational culture and successful project management}

Organizational culture - like the subconscious - affects the aspirations, attitudes and behavior of employees. It focuses their actions along routine tracks in a nonverbal, imperceptible manner. Therefore, culture can be used to encapsulate all that is omitted from a written contract, offering it up as an all-encompassing psychological contract to address different situations (Camerer and Vepsalainen, 1988). By influencing and consolidating certain attitudes and behaviors of employees, it may not be conducive of effective actions - it may even counteract them. Obviously, it can also support the functioning of an organization by facilitating human interactions.

Organizational culture is a concept which combines all of the various activities undertaken in an enterprise (including PM). This means that the implementation of PM can result in transformations in organizational culture. In turn, attributing the proper characteristics to an organizational culture beforehand can lead to favorable circumstances for the implementation of PM. The Organizational Competence Baseline (International Project Management Association, 2016), as a guideline for setting up an appropriate organization for PM, emphasizes organizational alignment, which includes processes, structures and culture. Kerzner (2000) states that PM is more similar to a culture than policy or procedures. Finally, Cleland states that "project management meets the need for providing an organizational focus not found in the traditional form of organization. However justified, project management should not be used until the leaders of the organization are committed to its use and are willing to prepare a suitable culture for project management to germinate and grow" (Cleland, 1994, cited in Du Plessis and Hoole, 2002).

The literature on PM presents the issue of a specific culture, which covers strictly defined features that support the implementation of changes in an organization or in teamwork. At this point, however, it is worth emphasizing that in papers addressing the problem of PM, such terms as "project culture," "project management culture," "project climate" and "project environment" function interchangeably (Du Plessis and Hoole, 2006). The climate, in turn, is only an external, easily observable layer of culture and stands for the subjective feelings of employees when referring to the atmosphere in the workplace (Ostroff et al., 2012).

The review conducted by Henrie and Sousa-Poza (2005) spanning the years 1993-2003 indicated that culture was not a widely reported or discussed topic in PM literature (journals specializing in PM). Today, we can say that various cultural aspects of PM are a popular research topic. A total of 557 documents were returned in a search of the Scopus database on February 28, 2020, with the following combination of queries: TITLE-ABS-KEY ("project management" AND "culture") AND (LIMIT-TO (DOCTYPE, "ar") AND (LIMIT-TO (SUBJAREA, "BUSI") AND (LIMIT-TO (LANGUAGE, "English"). Another situation is when we search using more detailed terms like "project management culture" or "project culture". The query "TITLE-ABS-KEY ('project culture') AND (LIMIT-TO (DOCTYPE, 'ar') AND (LIMIT-TO (SUBJAREA, 'BUSI') AND (LIMIT-TO (LANGUAGE, 'English')" resulted in 33 documents and "TITLE-ABS-KEY ('project management culture') AND (LIMIT-TO (DOCTYPE, 'ar') AND (LIMIT-TO (SUBJAREA, 'BUSI') AND (LIMIT-TO (LANGUAGE, 'English')" resulted in only in seven articles.

For example, Belassi et al. (2007) found a significant relationship between culture, a positive work environment with strong leadership and the success of projects for developing new products. A "positive work environment" refers to the perception of employees that it is their performance which matters most to their organization and that they feel free to open dialogues with their bosses. "Strong Leadership" means that long-term goals are the focus of all of top management's decisions and that employees are encouraged to keep trying if they fail in the process of creating something. Data for this research were collected from 95 manufacturing companies in the USA. 
Ajmal and Koskinen (2008) discussed the impact of organizational culture on knowledge transfer in "non-project businesses" who adopt a "project-style" approach. The problem of such organizations is that knowledge created in one project is not transferred to future projects. The authors stated that for effective knowledge transfer in project-based businesses, it is the organizational culture must be ready to accept and adopt new ways to transfer knowledge. The role of project managers is to form one project culture out of differing organizational and professional cultures and to promote effective knowledge management.

The findings of Nguyen and Watanabe (2017) in the construction industry show that alignment of goals, the commitment of contractors and a focus on workers all lead to better performance and satisfaction among those involved. Labor productivity can be predicted using only two indicators of culture: contractor commitment and a cooperative attitude. In order to predict learning performance, goal alignment, trust and contractor commitment are key.

Morrison et al. (2008) provided evidence that organizational culture correlates with the effectiveness of PM. In particular, one should look to the relatively strong link between effective PM and such values as respect and interfunctional integration. Their study was conducted among matrix organizations representing a wide variety of industries. The majority were civil engineering consultancy firms $(28 \%)$, while the other participating organizations were from the defense industry $(17 \%)$, the government sector $(14 \%)$, the industrial engineering and manufacturing sector $(14 \%)$ and the finance and insurance industry $(10 \%)$; the remaining participants $(17 \%)$ came from the mining, national parastatal, telecommunications and information technology (IT) industries.

In turn, Graham and Englund (1997) outlined their eight factors which lead to successful projects: strategic emphasis, upper management support, project planning support, customer/end-user input, project team development, project execution support, communication and information system and organizational support. With these factors in place, teamwork and interfunctional tasks are emphasized, conflicts are identified and resolved and perfection is the driving force (Larson and Gray, 2011).

In addition, project culture is based on values such as mutual trust, respect, open communication and risk and conflict tolerance of the disciplines, combined with a flexible, results-based approach and support and faith in making the right decisions, kindness and adherence to professional ethics (Pinto and Slevin, 1987).

Some researchers have addressed the issue of national culture's influence on project outcomes. Building on Hofstede's work (Hofstede, 1998), they feel that national culture shapes organizational culture, which, in turn, affects the execution of projects. Hofstede delineated such cultural dimensions as power distance, the degree of uncertainty avoidance, individualism and collectivism and long- or short-term orientation. Attention is primarily drawn to projects carried out by international teams and the fact that education in cultural differences can be necessary for them to be successful (Shore and Cross, 2005). For example, the high power distance typical of people from Hong Kong can lead to the acceptance of inequality and the legitimacy of power groups within a project (Rowlinson and Root, 1996). The impact of national differences on the specific tasks which make up PM, e.g. risk management, has also been analyzed. Risk is perceived and dealt with differently in different cultures. For example, one commonly held notion about Polish culture is the avoidance of uncertainty. This cultural trait can result in many rigorous terms and conditions being included in agreements with contractors (Liu et al., 2015).

National culture is also thought to play a role in the use of PM, in terms of the level of knowledge in this field and the extent of staff involvement in project work, as well as the adaptation of project discipline by individuals and groups. There is evidence that this deployment negatively correlates with both power distance and uncertainty avoidance but does not correlate with measures of individuality or masculinity (Bredillet et al., 2010). 
IJMPB 14,6

There are many typologies of organizational cultures. Some of these locate organizational culture within the intensity scale of one feature (e.g. Hall's concept, (Hall, 1976)). Others are more complex, based on more than one dimension (e.g. the typology of Cameron and Quinn (2011)). For example, Kivrak et al. (2014) used Hall's typology (Hall, 1976) to illustrate how national culture determines knowledge sharing in an international project team. This typology distinguishes high- and low-context cultures. The messages in a lowcontext culture are unambiguous and fairly accurately reflect the speaker's intentions, requiring little additional context and leaving little room for interpretation. In the case of high-context communication, the message can be ambiguous and can constitute a strong barrier in the process of tacit knowledge sharing, according to some studies. Such cultural features as hierarchy and competition can also be an obstacle to knowledge sharing in international project teams. Kivrak et al. (2014) also showed that collectivism is conducive to knowledge sharing, though only within a project team (not with outsiders).

Silva and Gomes (2015) conducted research focusing on the typology of cultures proposed by Handy (1983), who identified four characteristic types of organizational culture: power-, role-, goal- and people-oriented cultures. It is worth noting here that the goal culture is directly referred to as the task or project-oriented one. Organizations oriented toward goals treat tasks and their implementation as the most important issue. Individual competences and their contributions to specific actions are what matters most. Teams which follow these principles are able to easily adapt to the requirements of the situation. Groups and task teams are formed for specific purposes which determine the point behind their existence. Such a team works fast and makes decisions quickly. Individual team members enjoy flexibility and freedom but also face the responsibility for their work. The effects matter. Mutual relationships are usually quite loose, based more on the value of skills and input than age and formal status. The focus on action allows problems to be solved through discussions and negotiations, which provides a sense that solutions are created together. Such teams usually thrive in a dynamic and highly competitive environment. The qualitative research based on surveys with 12 respondents carried out by the abovementioned authors shows that diverse cultural types are present in different organizations which implement projects. The characteristics of the particular industry (e.g. energy, government or university) are important here. In addition, projects can be successful when other factors - apart from culture - also affect this success (e.g. selection of an appropriate PM methodology).

Although the studies presented above were focused on the cultural typologies by Hall and Handy, the hypothesis can be formulated that the typology of organizational cultures by Cameron and Quinn (2011) is most often discussed in studies addressing PM problems, although the output of management sciences includes numerous classifications of organizational cultures. The assessment tool proposed by these authors, the competing values framework (CVF), allows a company to identify a dominant cultural type across six key characteristics: dominant characteristics, leadership, human resources management (HRM), organizational glue, strategic emphasis and criteria of success. The CVF explains the complex nature of culture according to two dimensions: internal/external focus and stability/flexibility structure. These two dimensions create four quadrants, which represent four culture types: clan, adhocracy, hierarchy and market.

Clan culture is connected with a friendly, almost family-like atmosphere. A manager is treated as a mentor. The glue of an organization is loyalty and tradition. The key to success is usually taking care of the needs of clients and employees. The values are teamwork, participation and consensus.

Adhocracy comes from the Latin term "ad hoc," which means "for this special purpose" and by extension and improvised. Adhocracy is a corporate culture which is based on the ability to adapt quickly to changing conditions - which can we define as agility. Organizations with such culture are characterized by flexibility, creativity, employee empowerment and an emphasis on individual initiative (with risk-taking). Although 
corporate levels exist in an adhocracy, they are less strictly defined than in more hierarchical environments. In a more general sense, adhocracy contrasts with bureaucracy, which is characterized by inflexibility and a rigid adherence to rules.

Hierarchy culture means a working environment which is structured and formalized. Employees use defined procedures in carrying out their everyday tasks. The values are effective coordination and order. The primary goal is to maintain effective functioning and stability, and the results are achieved by performing tasks efficiently. Success is defined by good planning and low costs.

Finally, market culture focuses on customer satisfaction and shareholder value. It emphasizes targets and deadlines. People are competitive and focused on goals. Leaders are hard drivers, producers and rivals. They can be tough with high expectations. The emphasis on winning keeps the organization together. Reputation and success are the most important. Long-term focus is on rival activities and reaching goals. Market dominance, achieving goals and great metrics are the definitions of success. Competitive prices and market leadership are important. The organizational style is based on competition.

For example, the research conducted by Yazici (2009) in the USA involving 86 project managers in 76 companies indicated a strong correlation between clan culture and high project effectiveness and overall organization performance. It appears that this type of culture - one focused on employee participation, social cohesion, shared values, commitment and high morale - guarantees that project goals will be achieved, client expectations will be met within the adopted time frame and satisfaction among team members will be high. Among the hypotheses presented by Yazici, attention should be paid to one in particular: "Project maturity and organizational culture have a joint impact on project implementation." This joint impact, however, was not confirmed by the study. In total, $56 \%$ of the respondents were from the service sector (IT, banking, education, healthcare, consulting, retail and utility); $34 \%$ were from the manufacturing sector and only $10 \%$ were from government or construction.

Adhocracy and clan cultures have positive effects on tacit-oriented knowledge management strategy (Keskin et al., 2005). Wiewióra et al. (2012) in their research focused on knowledge management in projects. It was confirmed that clan culture - which promotes a collaborative environment in which people are encouraged to communicate - facilitates knowledge sharing between project team members. In turn, market culture, centered around such values as competitiveness, achievements and the focus on performance measurements, will probably hamper knowledge and skill sharing within the project. However, according to a study by Piwowar-Sulej (2014), projects can be also successfully completed in organizational cultures with dominant "hierarchical-market" features.

Similar conclusions were drawn by Mashiane (2013), who conducted research in a division of telecommunications company. The questionnaire was based on the management skills assessment instrument (MSAI) developed by Cameron et al. (2006) and on the project management culture assessment tool (PMCAT) developed by Du Plessis (2005). A marketoriented culture was identified as the dominant one in the organization under study. This was not surprising for the researcher because the organization provides infrastructure hosting solutions and technical support to external clients. The strategy of the organization focuses on the market or on clients, and success is defined in terms of client satisfaction and retention. The second most dominant type of culture was adhocracy.

Finally, according to 50 human resources (HR) specialists from medium-sized and large companies, the most suitable culture for PM is adhocracy (Piwowar-Sulej, 2016). These results are surprising in the context of new developing HRM concepts, such as sustainable HRM, which promotes long-term orientation and HR development (Stankevičiūtè and Savanevičienè, 2019; Piwowar-Sulej, 2021). It should be mentioned that in the long run, adhocracies can turn out to be effective organizations, though they do not offer stable workplace environments. 
IJMPB 14,6

1276
Table 1.

Traditional vs agile project management own study based on Špundak (2014), Cohen (2019), PiwowarSulej (2020)

\section{Project management methodologies}

As mentioned before, there are two main types of PM methodologies, i.e. the traditional one (Project Management Body of Knowledge - PMBoK - or Prince2) and the modern/agile one (which is more flexible, e.g. Scrum). Table 1 presents a comparison of these two approaches to PM.

The traditional methodology involves the mechanistic division of work, with an underlying assumption of manageability and predictability (Saynisch, 2010). This approach is synonymous with the waterfall methodology. It was first outlined in 1970 by Royce, an American computer scientist and director at Lockheed Software Technology Center in Texas, as a response to managing the increasingly complex nature of software development. This approach takes the perspective that rigorous, hierarchical control best manages complexity.

The waterfall methodology is sequential. One phase continues downstream into the next stage. Each stage in this process is self-contained. The project work starts by collecting and analyzing requirements, designing a solution, implementing the solution and fixing any issues. The initial phases of the project are intended to set the stage for all project work, as well as establishing the project's scope and the requirements that are necessary to deliver it (Thomas and Fernández, 2008). It is also heavily focused on requirements. One needs to have a crystal clear idea of what the project will demand before proceeding further. There is no room for correction once the project is underway.

Agile is a term which formally came into being in 2001 when several IT representatives released the "Agile Manifesto" during a meeting of 17 major players of new software development methodologies in Snowbird, Utah. Agile means "able to move quickly and easily" or "able to think quickly, mentally acute, or aware" (Dictionary.com, 2020). Agile is used as a term which characterizes a given way of thinking (mindset) about complex task management (from projects to entire organizations), including openness toward change and high flexibility. The notion is also used in relation to all agile PM methodologies (e.g. Scrum, Extreme Programming or the dynamic systems development method), which are based on principles outlined in the Agile Manifesto (Agilemanifesto.org, 2020).

\section{Traditional project management}

General characteristics

(1) Waterfall approach

(2) End users are not involved in later project stages

(3) The project manager is a formal manager, coordinator, hard-driver and producer

Advantages

(1) Ease of use: this model is well known and thoroughly operationalized

(2) Structure: there is clear demarcation between project stages

(3) Documentation: the focus is on explicit knowledge, which is easier to share

\section{Disadvantages}

(1) Higher risk: compared to the lower risk in the agile approach

(2) Front-heavy: requirements should be understood correctly in the early stages
Agile project management

General characteristics

(1) Iterative approach

(2) Flexibility

(3) End users are involved in later project stages

(4) There is no formal manager. This approach promotes coaching and mentoring and facilitates project teams

Advantages

(1) Flexibility and freedom: there is more room for experimentation and incremental changes

(2) Lower risk: there is regular feedback from stakeholders, which enables changes to be implemented quickly

\section{Disadvantages}

(1) No fixed plan: resource management and scheduling are more difficult

(2) Collaboration-heavy: all parties involved must be able to work together closely and be available in order to give feedback quickly 
The reason for declaring the Agile Manifesto was the increasing number of failed software development projects which were based on the waterfall approach. The inefficiency of the waterfall approach was and is connected with one of the basic assumptions of this model, i.e. focusing on delivering an IT project in the form which was specified in the first stage. Moreover, a project is carried out in organized, distinct and - in most cases - lengthy stages which makes it difficult to verify results in the course of the project. This way of working is not conducive to a culture of cooperation and ongoing communication, and it has a negative impact on the end result of a project.

The essence of agile PM lies in the fact that a project's goals are defined in less detail at the start of the project. The project schedule is also prepared approximately. The work is divided into equal iterations with assigned parts of the project scope. "In the beginning a team undertakes the most important functions, while leaving the least important ones for the end. Less important demands can later be omitted on the basis of the results of already finished iterations, the client's changed wishes/requests, the performers' proposals, or changes in the environment. A detailed specification of the iterations' products and precise scheduling of the iterations (the way of implementing, tasks, hours of work, performers, etc.) is created at the beginning of each iteration, taking into account the current results, new insights, the client's new wishes, or the ideas of developers, as well as changes to the original assumptions and requirements" (Stare, 2014, p. 297). The project team - not the formal project manager - is responsible for the execution plan and making the iterations.

Scrum is one of the agile PM methodologies. It implements working in "sprints" of 30 days and also focuses heavily on daily meetings ("daily scrum") which are typically held in the same location and at the same time of day (preferably in the morning). The formal role of a project manager does not exist. There is a role of Scrum Master: a person who helps the team perform at the highest level. He/she also protects the team from both internal and external distractions and tries to fulfill Scrum values. The ideal size for a development team is between three and nine people, not including the Scrum Master and product owner. The team is self-organizing, cross-functional and as a team has all the skills necessary to create a product increment. There is no formal hierarchy within the teams. Scrum recognizes no titles for development team members, regardless of the work being performed by the person. Team members choose the project tasks themselves according to collective agreements, their skills and other factors (e.g. time). People who work on a team cannot be involved in other projects (Schwaber and Sutherland, 2017).

Andersen (2006) states that an organization should apply methodologies assigned to specific types of projects. According to Cohen (2019), traditional PM methodologies are best for short, simple projects, projects with clear and fixed requirements and projects with changing resources that depend on in-depth documentation, while the agile approach is appropriate for projects with no fixed end (with only a general idea of a product), when the project needs to accommodate quick changes and if collaboration and communication are more important than planning. Cohen emphasizes not only objective project characteristics, e.g. duration or complexity (with its many dimensions, see (San Cristóbal et al., 2018)), but also organizational values (bureaucracy vs collaboration). The significance of organizational culture in comparison to objective project characteristics seems to be an interesting research topic.

Taking into account the objective project characteristics, it is worth noting that there is no common agreement on this issue. For example, Jovanović and Berić (2018) found that general characteristics of traditional methodologies (e.g. Project Management Institute [PMI] or International Project Management Association [IPMA] make them more suitable for larger and more complex projects, such as investment or manufacturing, while agile methodologies are more appropriate for use in IT projects and some smaller and less complex projects, such as devising various studies, project reports, etc. Stare (2014) noted that almost all research studies published between 1999 and 2009 and focused on the agile approach referred to IT projects.

Organizational culture

1277 
IJMPB 14,6

Špundak (2014) states that there are factors other than the characteristics of projects which determine the choice of PM methodology. Traditional PM methodologies are recommended if there is a lack of agreement between project team members or a huge fluctuation of project team members during the course of the project or if the contact between team members is more virtual. It is also possible that the nature of cooperation with external partners (contractors or suppliers) will be an important criterion in the selection of an appropriate PM methodology.

The relationship between specific features of organizational culture and PM methodology is an interesting research problem, as well. The features of "project management culture" presented above, such as trust or open communication, are so general that they will stimulate projects regardless of the PM methodology used. When trying to assess a relationship between a culture and a methodology, it is worth taking into account cultural differences which are highlighted in organizational culture typologies.

Llanos et al. (2017) found that adhocracy culture has more positive impact on organizational agility than clan culture. On the basis of above-presented characteristics of agile PM, one can state that they are similar to clan culture or adhocracy culture, while the features of traditional PM are similar to hierarchy culture. However, at this point, it is worth highlighting the fact that the hybrid PM approach is currently being implemented as a combination of traditional and agile PM methodologies. In general, this new approach takes the best parts of both waterfall (e.g. a work breakdown structure) and agile (speed and leanness) and combines them in a flexible but structured approach. In hybrid, the planning is done using the waterfall approach, while the execution and delivery are handled by the agile method (Cooper, 2016).

These findings, which are based on literature studies, led to the following research questions:

$R Q 1$. What significance is attributed to organizational culture compared to the objective project characteristics when choosing the dominant PM methodology in organizations?

RQ2. Which type of organizational culture is preferred for successful implementation of different PM methodologies?

RQ3. What kind (if any) of relationship exists between the dominant type of organizational culture in organizations and the dominant PM methodology?

\section{Research methodology}

This study investigates a subject that is rooted in two academic disciplines: HRM (and/or organizational behavior) and PM. Figure 1 presents the stages of the research process used for the purposes of this study. An exploratory and descriptive research design was chosen in order to identify the determinants of the choice of PM methodology and the abovementioned relationships between different factors and PM methodologies. The interpretative approach was used in this study, which means that the perceptions of the cultural factor from the viewpoint of practicing project managers were recognized as important (Du Plessis and Hoole, 2006).

In order to eliminate biases, one should take into account the significant differences in organizational environment and types of projects. Thus, the research included 100 project managers working in different companies from the same industry. Companies from a given sector are influenced by the same external factors (the industry macroculture) - legal regulations - for example.

The respondents were employed in medium-sized and large enterprises (i.e. those which employ over 50 people) of the financial sector in Poland (banking, financial services, leasing 


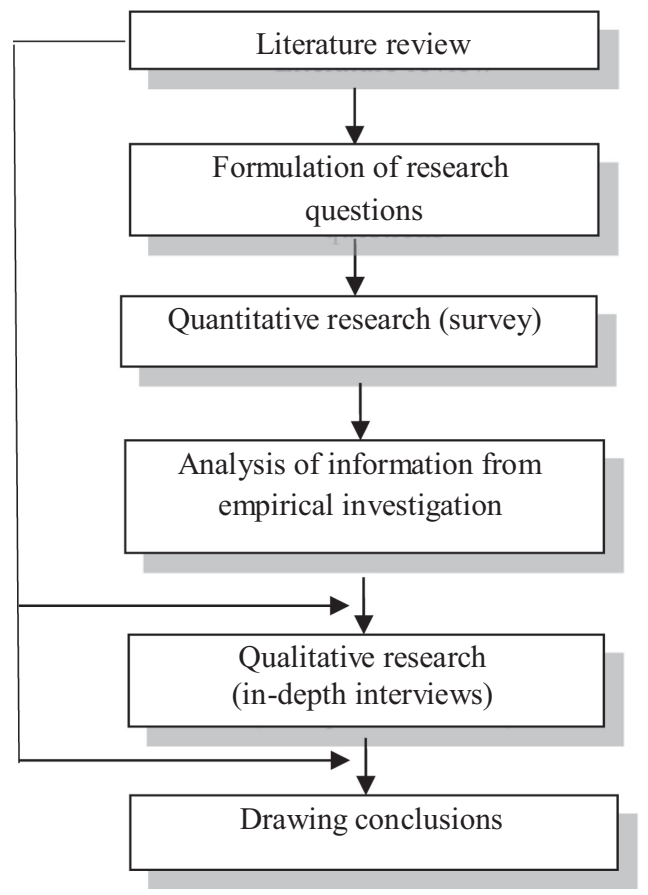

Organizational culture

1279

Figure 1.

The research process

and factoring). This industry implements many technological innovations in the form of projects. Important projects are aimed at developing security and risk management. The convenience for customers using financial services is also changing. Around 7-8 years ago, new-generation IT systems began to appear, replacing the previous ones which were based on a tabular approach. It was understood that the client not only needs accounting statements but also wants to learn how to spend and invest their money. Personalized solutions are also important. New products and services are constantly emerging. In addition, due to the changing and very restrictive legal regulations (e.g. regarding protection of personal data), companies are forced to implement changes in processes and IT systems. One can state that these regulatory projects take top priority and are often selected at the expense of other nonregulatory projects. The PM maturity level in the financial industry is high - in comparison with other industries in Poland (Wyrozebski et al., 2012).

According to data from the Central Statistical Office, in 2018, this sector consisted of main players such as 15 banks with private capital, 13 insurance companies, 47 companies specializing in credit intermediation or lending from their own funds, 11 factoring companies and 38 leasing companies (Statistics Poland, 2019). It is worth noting that many companies run more than one business activity at the same tame (e.g. credit and leasing intermediation or leasing and factoring).

In order to collect the contact information of respondents, companies were selected from a list created from information accessible in secondary sources (listings of companies, websites, industry newsletters, etc.). The research, based on a quantitative approach, was conducted in December 2019 and January 2020. In the process of gathering information in the survey, the personal structured interviews (paper-and-pencil interview [PAPI) method was used. The direct contact with respondents helped to avoid misunderstandings about the questions. Interviews with each of the respondents lasted about three hours. The interview 
IJMPB 14,6

\section{0}

questionnaire was designed for the purposes of a larger research project. This paper presents only the results which are pertinent to the chosen research questions and cultural typology, based on the CVF.

Statistical analyses were conducted with the use of IBMSPSS software. For the purpose of this paper, Pearson's chi-squared test and the Kruskal-Wallis test were used. These tests examine the relationship between two variables when at least one is qualitative. The chisquared test allows the researcher to examine the significance of differences in percentage structures. It is based on comparing observed values (i.e. those obtained in the study) with expected values (i.e. those assumed by the test if there were no relationship between the variables). If the difference between the observed and expected values is large (statistically significant), it can be stated that there is a relationship between the two variables.

For the correct interpretation of the findings of the quantitative research, the in-depth interview method was used. Such interviews can provide much more information which builds a context to previous outcome data. They offer a more complete picture of the state and causes of a research problem. In total, three direct, unstructured interviews with project managers (from a bank, a leasing company and a credit provider) were used. Each of them lasted about one hour.

\section{Results and discussion}

At first, it is worth presenting the general characteristics of the industry in question. The CVF has already been discussed in relation to organizational culture in banking by Thakor (2015), though the author did not conduct any empirical research on this topic. He only presented the assumptions of the CVF concept and implications for managers in banking. In turn, Barth (2015) showed that different types of organizational culture have different preferences for risk-taking. He found that banks with a market-oriented organizational culture have higher excess returns. Finally, Joseph and Kibera (2019) found that clan and hierarchy are the dominant cultural types in the microfinance industry in Kenya.

During the interviews conducted for this study, the dominant and secondary cultural types in the companies were identified. Table 2 shows the three cultural types which were indicated as being the dominant cultural type in the respondents' organizations as well as the dominant PM methodology used in the companies under study. Analysis revealed similar findings to above-presented resulted from research by Joseph and Kibera (2019).

Clan culture - emphasizing development of shared understanding and commitment instead of a formalized communication process - is the most popular cultural type. At the same time, the cultural type most often indicated as a secondary one was market culture (54 responses). This type of culture is a results-oriented one. The "second" culture type in the survey was defined as one which simultaneously coexists with the first but is less expressed. The commonality between hierarchy culture and market culture is that both focus on stability and control. The difference lies in the fact that market culture promotes fast changes, while hierarchy lends itself more to incremental changes. In turn, adhocracy and market cultures have an external focus in common. The most interesting result is the combination of

Table 2.

Cultural types regarded as dominant and the popularity of different PM methodologies in respondents' companies

\begin{tabular}{lclc}
\hline $\begin{array}{l}\text { Cultural type indicated as the } \\
\text { dominant one }\end{array}$ & $\begin{array}{c}\text { The number of } \\
\text { responses }(N=100)\end{array}$ & $\begin{array}{l}\text { Dominant PM } \\
\text { methodology }\end{array}$ & $\begin{array}{c}\text { The number of } \\
\text { responses }(N=100)\end{array}$ \\
\hline Clan & 61 & Traditional & 30 \\
Hierarchy & 17 & Agile & 31 \\
Adhocracy & 13 & Hybrid & 39 \\
Market & 9 & &
\end{tabular}


clan and market cultures because they are focused on completely different issues. The latter is focused on the outside of an organization, differentiation and fast changes, while the former focuses on flexibility, integration and long-term changes. These contrasting cultural types are combined in the form of employee participation (clan) linked with costumer focus (market). They can be also found together in hybrid PM methodology, which was the most popular one in the companies under study (Table 2).

The in-depth interviews demonstrated that hybrid methodology was implemented because of problems with other, previously used PM approaches. At the beginning, the waterfall approach was used. A few years ago, agile PM methodology was implemented as a trendy new approach. However, numerous barriers have been noticed in the successful development of projects. Despite many years of working together, the employees had significant problems carrying out their new roles or even problems transferring their current roles to the new model. Other barriers were the unavailability or insufficient availability of internal clients and communication problems. The dominant position of traditional methodologies in the organization is associated with certain employee habits. The implementation of novelty in the form of agile moved them out of their comfort zone. The hybrid approach provided compliance with employee expectations, which is a characteristic of clan culture.

In addition, the priorities in some organizations change quite often (adhocracy culture) because of changes in legal regulations and - in the case of leasing companies - changes in the operations of the banks which finance the assets. The agile approach seems to be the most suitable in such situation. In turn, "hierarchical" banks had to meet the challenges in terms of ensuring the agile model's compliance with legal requirements. Official legal regulations emphasize a strong and active role of the bank's management board in the decision-making process and in the organization of day-to-day operations (hierarchy). The agile model assumes a limited role of the managing body. The management board is supposed to set the strategic goals but without interfering or supervising - choosing the way the goals are met. The hybrid approach allowed organizations to reconcile the business and legal requirements.

Respondents were asked about which factor has a greater impact on the project methodology used in the organization. They had the three following options to choose from: organizational culture $(\mathrm{OC})$, project characteristics (e.g. duration, complexity, innovativeness and scope of cooperation with external partners) $(\mathrm{P})$ and equal importance of organizational culture and project characteristics $(\mathrm{OC}+\mathrm{P})$. The results are shown in Table 3 .

The findings are partially in line with Spundak's (2014) statement that there are other factors than projects' characteristics which influence the choice of PM methodology. Organizational culture is seen to be a more important factor $(n=41)$ than objective project characteristics $(n=27)$ in the context of choosing the dominant PM methodology in

\begin{tabular}{|c|c|c|c|c|c|c|c|}
\hline & & & \multicolumn{3}{|c|}{$\begin{array}{l}\text { Factors determining the } \\
\text { choice of project } \\
\text { management methodology }\end{array}$} & \multirow[b]{2}{*}{ Total } & \\
\hline & & & $\mathrm{OC}+\mathrm{P}$ & $\mathrm{OC}$ & $\mathrm{P}$ & & \\
\hline \multirow[t]{4}{*}{ PM methodology } & Traditional & $\begin{array}{l}\text { Count } \\
\text { \% within PM methodology }\end{array}$ & $\begin{array}{c}8 \\
26.7 \%\end{array}$ & $\begin{array}{l}17 \\
56.7 \%\end{array}$ & $\begin{array}{l}5 \\
16.7 \%\end{array}$ & $\begin{array}{c}30 \\
100.0 \%\end{array}$ & \\
\hline & Agile & Count & 9 & 12 & 10 & 31 & Factors taken into \\
\hline & & \% within PM methodology & $29.0 \%$ & $38.7 \%$ & $32.3 \%$ & $100.0 \%$ & account in the decision- \\
\hline & Hybrid & Count & 15 & 12 & 12 & $\begin{array}{l}39 \\
1000 \%\end{array}$ & making process about \\
\hline \multirow[t]{2}{*}{ Total } & & 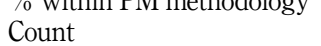 & $\begin{array}{l}38.5 \% \\
32\end{array}$ & $\begin{array}{l}30.8 \% \\
41\end{array}$ & $\begin{array}{l}50.8 \% \\
27\end{array}$ & $\begin{array}{l}100.0 \% \\
100\end{array}$ & $\begin{array}{l}\text { appropriate PI } \\
\text { methodology }\end{array}$ \\
\hline & & $\%$ within PM methodology & $32.0 \%$ & $41.0 \%$ & $27.0 \%$ & $100.0 \%$ & frequency distributio \\
\hline
\end{tabular}


IJMPB 14,6

\section{2}

organizations; however, a chi-squared test did not reveal any significant relationships between the factors taken into account $\left(\chi^{2}[4, N=100]=5.40 ; p=0.249\right)$.

The research therefore shows that other factors or a bundle of factors should be taken into account when analyzing the basics of decision-making on the choice of a particular PM methodology. Špundak (2014) believes that the company size can play a role. He hypothesizes that large organizations are more likely to use the traditional approach because it helps them to control the work. However, the respondents who participated in this study worked in medium-sized and large companies, and the most frequently reported PM methodology was a hybrid one. As indicated in the in-depth interviews, such factors as the vogue for new PM approaches and the need to reconcile employees' needs (maintaining of tradition), business requirements (implementing innovations) and legal regulations are of great importance.

Results of previous research which utilized the CVF emphasized relationships between clan culture and project effectiveness (Yazici, 2009) and clan culture and knowledge sharing in a project team (Wiewiora et al., 2012). The presented research shows clan culture in a slightly different context. Table 4 presents the types of organizational culture that are preferred for successful implementation of different PM methodologies.

Within the traditional PM methodology, hierarchy culture $(70 \%)$ was considered to be the most appropriate environment; clan culture followed by adhocracy is considered being the most appropriate environment for agile approach. The results are reverse in relation to findings obtained by Llanos et al. (2017) in their research on the impact of organizational culture on the organizational agility. Contrary to expectations, this research also revealed a positive link between hierarchy culture and agile Approach. As Llanos et al. (2017) stated, such findings may suggest that certain features inherent to hierarchy culture lead to more agile management. Finally, according to the respondents, a successful implementation of hybrid PM methodology requires an adhocracy culture. The relationship between preferred cultural types in the context of different PM methodologies is statistically significant $\left(\chi^{2}[4, N=100]=81.47 ; p<0.001\right)$.

\begin{tabular}{|c|c|c|c|c|c|c|}
\hline & & & $\mathrm{PMr}$ & ethodolos & & \\
\hline & & & Traditional & Agile & Hybrid & Total \\
\hline Preferred type of organizational & Clan & Count & 9 & 0 & 21 & 30 \\
\hline culture (POC) & & $\begin{array}{l}\text { Expected } \\
\text { count }\end{array}$ & 8.4 & 13.5 & 8.1 & 30.0 \\
\hline & & $\begin{array}{l}\% \text { within } \\
\text { POC }\end{array}$ & $30.0 \%$ & $0.0 \%$ & $70.0 \%$ & $100.0 \%$ \\
\hline & Adhocracy & Count & 19 & 12 & 0 & 31 \\
\hline & & $\begin{array}{l}\text { Expected } \\
\text { count }\end{array}$ & 8.7 & 14.0 & 8.4 & 31.0 \\
\hline & & $\begin{array}{l}\% \text { within } \\
\text { POC }\end{array}$ & $61.3 \%$ & $38.7 \%$ & $0.0 \%$ & $100.0 \%$ \\
\hline & Hierarchy & Count & 0 & 33 & 6 & 39 \\
\hline & & $\begin{array}{l}\text { Expected } \\
\text { count }\end{array}$ & 10.9 & 17.6 & 10.5 & 39.0 \\
\hline & & $\begin{array}{l}\% \text { within } \\
\text { POC }\end{array}$ & $0.0 \%$ & $84.6 \%$ & $15.4 \%$ & $100.0 \%$ \\
\hline Total & & Count & 28 & 45 & 27 & 100 \\
\hline & & $\begin{array}{l}\text { Expected } \\
\text { count }\end{array}$ & 28.0 & 45.0 & 27.0 & 100.0 \\
\hline & & $\begin{array}{l}\% \text { within } \\
\text { POC }\end{array}$ & $28.0 \%$ & $45.0 \%$ & $27.0 \%$ & $100.0 \%$ \\
\hline
\end{tabular}

Table 4 .
Cultural types matched with PM methodology - frequency distribution 
These findings were compared with the cultural types indicated as dominant in the respondents' organizations. Due to the low number of indications of the "Market culture" variant (Table 2) as the dominant cultural type, a reliable measurement with the chi-squared test of the relationships between all cultural types and PM methodologies in the organizations studied was not possible. However, focusing on only the three most popular types of organizational culture, it can be stated that there is no significant relationship between existing dominant cultural types and existing dominant PM methodology $\left(\chi^{2}[4, N=91]=1.02 ; p=0.907\right)$.

Next, a series of Kruskal-Wallis tests was conducted in order to examine whether there is a relationship between the dominant culture and the indicators of project effectiveness (see Table 5). The respondents noted the percentage of successful projects, taking into account criteria such as time, budget and scope requirements and achieving client, team member and supplier satisfaction.

Project success strictly depends on team members commitment (Araujo and Pedron, 2014), and Acar (2012) found that clan and adhocracy cultures have positive effects on employees' commitment. This study did not confirm previous findings that only clan culture ensures high project effectiveness (Yazici, 2009). The analysis revealed a statistically significant difference between the types of dominant cultural type and "Project completed within the project scope requirements" $\left(X^{2}[3]=10.75 ; p=0.013\right)$. The follow-up pairwise comparison showed that the project managers who chose hierarchy as the dominant cultural type $($ mean $=93.94$; median $=100)$ regarded project completion to be more successful than those who chose clan as the dominant culture (mean $=87.77$; median $=90 ; p=0.030$ ). No other statistically significant differences were found. The reason for these discrepancies can be a national culture and composition of team members related to their individual values. Yazici (2009) conducted research in the USA, while this paper presents research conducted in Poland. For respondents - project team members - the best cultural environment for traditional PM can be hierarchy; however, people working in projects can represent individual values congruent with adhocracy-specific values. This congruency contributes to organizational performance outcomes (Titov and Umarova, 2017).

As was highlighted during the in-depth interviews, measuring the impact that culture may have on project outcomes is difficult. The level of project success is influenced by many factors, both endogenous and exogenous. Internal factors include the competencies of the project team and individual values of team members. The competences - according to the respondents - seem to be the most important factor since highly skilled project managers and project team members can deliver high-quality project outcomes, despite an unfavorable organizational culture.

\section{Conclusions, implications and directions for further research}

This research contributes to knowledge by showing a linkage between the type of organizational culture and the type of PM methodology. In answer to RQ1, it can be said that organizational culture is seen as the most important factor which determines the PM methodology used as the standard in organizations. When it comes to RQ2, the results of both theoretical studies and empirical research show that the most appropriate cultural type for traditional PM is hierarchy. Clan culture is most suitable for agile PM approach, while adhocracy is best for hybrid PM methodology. Nevertheless, in practice, there is no relationship between the dominant type of organizational culture and the dominant PM methodology (RQ3). Moreover, projects - taking into account five out of the six project success indicators - are equally likely to be successfully completed, despite differences in organizational cultures.

There are several recommendations for management practice based on this research. Firstly, organizational culture can be developed intentionally (Gagliardi, 1986; Bendak et al., 2020). There 
IJMPB

14,6

1284

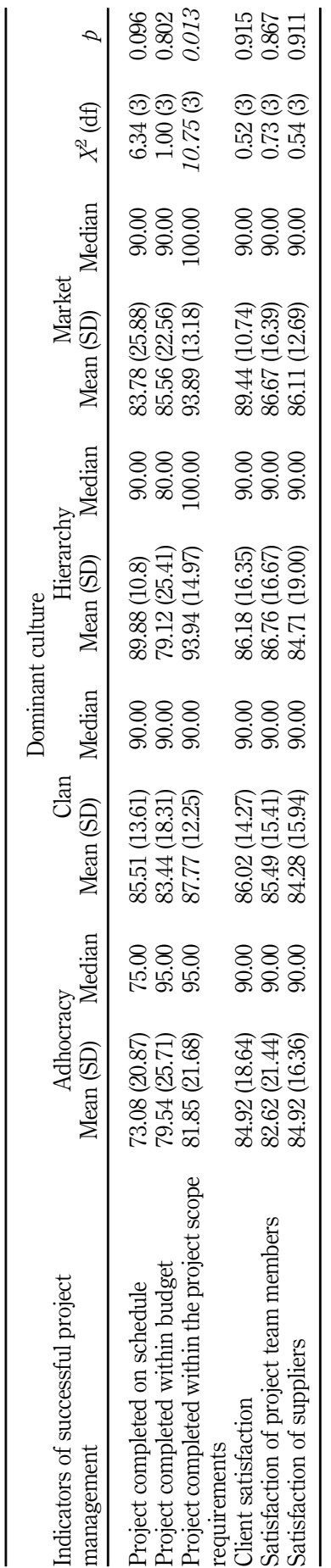

Table 5.

Dominant cultural type and project success results of KruskalWallis test 
is still room for improvement in the field of project effectiveness. The missing percentage of successfully completed projects could be made up with a more suitable organizational culture. Therefore, it is worth determining both current and expected cultural types by the use of survey and/or interviews among project team members and other employees. On this basis, managers should take up actions which will stimulate a cultural transformation of the company. They have to play a role of ambassadors of changes (Kane-Urrabazo, 2006).

If, for example, organizational culture should have more clan features, managers should turn to their employees, find what people value, use open feedback in order to collect employees' ideas and allow them to act. Inspirational motivation (by, e.g. trust and pushing decisions to the lowest levels, allowance for mistakes) and individualized consideration effects clan culture (Chan, 1997; Acar, 2012). Design of the workspace is also important. In clan culture, teams have to interact effectively with one another. Therefore, smaller footprints should be allocated to the individual than the team and workstation panel heights should be lower, if not nonexistent (ISS, 2020). In turn, transformation into more hierarchical culture requires buttoning up processes, ensuring clear goals for teams and individuals and a workspace which provides a sense of stability. Management-by-exceptions also effects hierarchy culture (Acar, 2012).

Secondly, human competencies are of the utmost value. A good understanding of the cultural aspects of PM is also emphasized. Conscious project managers and highly skilled team members will be able to deliver a high-quality product despite an unfavorable organizational culture. There is a need to develop not only technical but also cultural competences. The importance of these competencies has been so far discussed but mainly in the context of multinational projects (Isern, 2015; Vlahov et al., 2016). Training in this issue is a developmental field for educational institutions.

This paper has two main shortcomings, though it nevertheless provides directions for future research. Firstly, the sample population in this study was collected from project managers working for companies in the financial industry in Poland. In order to extend the applicability of the findings, more samples from different industries - and even from different countries - should be studied. Secondly, all respondents were project managers who volunteered to participate in this research. They subjectively assessed the dominant and coexisting cultural types of their companies. Since the companies were of medium and large size, their organizational culture may be fragmented. This means that different divisions of the organizations can represent slightly different cultural types. Future studies could overcome such a limitation. Further triangulation of the methods and the involvement of more respondents from a single company can be used in order to achieve more objective measures and to identify the mechanism of choosing the PM standards. Further research can also adopt different cultural typologies than those presented by Cameron and Quinn.

\section{References}

Acar, A.Z. (2012), "Organizational culture, leadership styles and organizational commitment in Turkish logistics industry", Procedia - Social and Behavioral Sciences, Vol. 58, pp. 217-226, doi: $10.1016 /$ j.sbspro.2012.09.995.

Agilemanifesto.org (2020), “Agile Manifesto”, available at: https://agilemanifesto.org/.

Ajmal, M.M. and Koskinen, K.U. (2008), "Knowledge transfer in project-based organizations: an organizational culture perspective”, Project Management Journal, Vol. 39 No. 1, pp. 7-15, doi: 10. 1002/pmj.20031.

Alvesson, M. (1990), "On the popularity of organizational culture”, Acta Sociologica, Vol. 33 No. 1, pp. 31-49, doi: 10.1177/000169939003300103.

Andersen, E.S. (2006), "Toward a project management theory for renewal projects", Project Management Journal, Vol. 37 No. 4, pp. 15-30, doi: 10.1177/875697280603700403. 
IJMPB 14,6

Araujo, C.C.S.D. and Pedron, C.D. (2014), "IT project management success: the influence of project manager competencies and team commitment", Proceedings of the 11th CONTECSI International Conference on Information Systems and Technology Management, TECSI. doi: 10.5748/9788599693100-11CONTECSI/PS-588.

Barth, A. (2015), "The role of corporate culture in the financial industry", Annual Conference 2015 (Muenster): Economic Development - Theory and Policy 112922, Frankfurt, German Economic Association, available at: https://farapaper.com/wp-content/uploads/2018/09/The-Role-ofCorporate-Culture-in-the-Financial-Industry.pdf.

Belassi, W., Kondra, A.Z. and Tukel, O.I. (2007), "New product development projects: the effects of organizational culture”, Project Management Journal, Vol. 38 No. 4, pp. 12-24, doi: 10.1002/ pmj.20017.

Bendak, S., Shikhli, A.M. and Abdel-Razek, R.H. (2020), "How changing organizational culture can enhance innovation: development of the innovative culture enhancement framework", Cogent Business and Management, Vol. 7 No. 1, 1712125, doi: 10.1080/23311975.2020.1712125.

Berger, H. and Beynon-Davies, P. (2009), "The utility of rapid application development in large-scale, complex projects", Information Systems Journal, Vol. 19 No. 6, pp. 549-570, doi: 10.1111/j.13652575.2009.00329.x.

Bredillet, C., Yatim, F. and Ruiz, P. (2010), "Project management deployment: the role of cultural factors", International Journal of Project Management, Vol. 28 No. 2, pp. 183-193, doi: 10.1016/j. ijproman.2009.10.007.

Camerer, C. and Vepsalainen, A. (1988), "The economic efficiency of corporate culture", Strategic Management Journal, Vol. 9 No. S1, pp. 115-126, doi: 10.1002/smj.4250090712.

Cameron, K.S. and Quinn, R.E. (2011), Diagnosing and Changing Organizational Culture, Based on the Competing Values Framework, 3rd ed., Jossey-Bass, San Francisco.

Cameron, K.S., Quinn, R.E., DeGraff, J. and Thakor, A.V. (2006), Competing Values Leadership: Creating Value in Organizations, Edward Elgar Publishing, Northampton.

Chan, A. (1997), "Corporate culture of a clan organization", Management Decision, Vol. 35 No. 2, pp. 94-99, doi: 10.1108/00251749710160232.

Cleland, D.I. (1994), Project Management - Strategic Design and Implementation, 2nd ed., McGraw-Hill, New York.

Cohen, E. (2019), "The definitive guide to project management methodologies", available at: https:// www.workamajig.com/blog/project-management-methodologies.

Cooper, R.G. (2016), “Agile-stage-gate hybrids”, Research-Technology Management, Vol. 59 No. 1, pp. 21-29, doi: 10.1080/08956308.2016.1117317.

Denison, D.R. and Mishra, A.K. (1995), "Toward a theory of organizational culture and effectiveness", Organization Science, Vol. 6 No. 2, pp. 204-223, doi: 10.1287/orsc.6.2.204.

Dictionary.com (2020), "Agile", available at: https://www.dictionary.com/browse/agile?s=t.

Drucker, P. (1992), "The new society of organizations", Harvard Business Review, Vol. 70 No. 5, pp. 95-104.

Du Plessis, Y. (2005), The Development of an Assessment Tool for Measuring Project Management Culture in Organisations, University of Pretoria, available at: http://hdl.handle.net/2263/25349.

Du Plessis, Y. and Hoole, C. (2002), "The development of a project management culture assessment framework", PMI® Research Conference 2002: Frontiers of Project Management Research and Applications, Washington, Poject Management Institute, available at: https:/www.pmi.org/ learning/library/development-pm-culture-assessment-framework-1938.

Du Plessis, Y. and Hoole, C. (2006), "An operational 'project management culture' framework (Part 1)", SA Journal of Human Resource Management, Vol. 4 No. 1, doi: 10.4102/sajhrm.v4i1.79.

Englund, R.L. and Graham, R.J. (1997), Creating an Environment for Successful Projects, Jossey-Bass Publishers, San Francisco. 
Gagliardi, P. (1986), "The creation and change of organizational cultures: a conceptual framework", Organization Studies, Vol. 7 No. 2, pp. 117-134, doi: 10.1177/017084068600700203.

Hall, E.T. (1976), Beyond Culture, Doubleday, New York.

Handy, C. (1983), Understanding Organizations, Oxford University Press, New York.

Hartog, D.N. and Verburg, R.M. (2004), "High performance work systems, organisational culture and firm effectiveness”, Human Resource Management Journal, Vol. 14 No. 1, pp. 55-78, doi: 10.1111/ j.1748-8583.2004.tb00112.x.

Henrie, M. and Sousa-Poza, A. (2005), "Project management: a cultural literary review", Project Management Journal, Vol. 36 No. 2, pp. 5-14, doi: 10.1177/875697280503600202.

Hofstede, G. (1998), "Attitudes, values and organizational culture: disentangling the concepts", Organization Studies, Vol. 19 No. 3, pp. 477-493, doi: 10.1177/017084069801900305.

International Project Management Association (2016), Organizational Competence Baseline for Developing Competence in Managing by Projects, IPMA, Amsterdam.

Isern, G. (2015), "Intercultural project management for IT: issues and challenges", Journal of Intercultural Management, Vol. 7 No. 3, pp. 53-67, doi: 10.1515/joim-2015-0021.

ISS (2020), "How office design can shape your company culture", available at: https://www. servicefutures.com/office-design-can-shape-company-culture.

Joseph, O.O. and Kibera, F. (2019), "Organizational culture and performance: evidence from microfinance institutions in Kenya", SAGE Open, Vol. 9 No. 1, doi: 10.1177/2158244019835934.

Jovanovic, P. and Beric, I. (2018), "Analysis of the available project management methodologies", Management:Journal of Sustainable Business and Management Solutions in Emerging Economies, Vol. 23 No. 3, p. 1, doi: 10.7595/management.fon.2018.0027.

Kane-Urrabazo, C. (2006), "Management's role in shaping organizational culture", Journal of Nursing Management, Vol. 14 No. 3, pp. 188-194, doi: 10.1111/j.1365-2934.2006.00590.x.

Kerzner, H. (2000), Applied Project Management. Best Practices on Implementation, John Willey and Sons, New York.

Keskin, H., Akgün, AE., Günsel, A. and İmamoğlu, S.Z. (2005), "The relationships between adhocracy and clan cultures and tacit oriented KM strategy", Journal of Transnational Management, Vol. 10 No. 3, pp. 39-53, doi: 10.1300/J482v10n03_04.

Kivrak, S., Arslan, G., Tuncan, M. and Birgonul, M.T. (2014), "Impact of national culture on knowledge sharing in international construction projects", Canadian Journal of Civil Engineering, Vol. 41 No. 7, pp. 642-649, doi: 10.1139/cjce-2013-0408.

Larson, E.W. and Gray, C.F. (2011), Project Management - The Managerial Process, 11th ed., McGrawHill Hills, New York.

Liu, J., Meng, F. and Fellows, R. (2015), "An exploratory study of understanding project risk management from the perspective of national culture", International Journal of Project Management, Vol. 33 No. 3, pp. 564-575, doi: 10.1016/j.ijproman.2014.08.004.

Llanos, C.M.F., Roldán, J.L. and Leal-Rodriguez, A.L. (2017), "Impact of organizational culture values on organizational agility”, Sustainability, Vol. 9 No. 12, p. 2354, doi: 10.3390/su9122354.

Lucas, L.M. (2006), "The role of culture on knowledge transfer: the case of the multinational corporation", The Learning Organization, Vol. 13 No. 3, pp. 257-275, doi: 10.1108/09696470610661117.

Martins, E.C. and Terblanche, F. (2003), "Building organisational culture that stimulates creativity and innovation”, European Journal of Innovation Management, Vol. 6 No. 1, pp. 64-74, doi: 10.1108/ 14601060310456337.

Mashiane, L. (2013), "Investigating an organisational culture conducive to project management, Essays Innovate", available at: https://www.up.ac.za/media/shared/Legacy/sitefiles/file/44/1026/ 2163/8121/innovate8/9195investigating_an_organisational_culture_conducive_to_project_ managementbyloriummashiane.pdf. 
IJMPB 14,6

Mathew, J. (2007), "The relationship of organisational culture with productivity and quality", in Budhwar, P.S. (Ed.), Employee Relations, Vol. 29, No. 6, pp. 677-695, doi: 10.1108/ 01425450710826140 .

Morrison, J.M., Brown, C.J. and Smit, E.V.D.M. (2008), “The impact of organizational culture on project management in matrix organizations", South African Journal of Business Management, Vol. 39 No. 4, pp. 27-36, doi: 10.4102/sajbm.v39i4.569.

Nguyen, L. and Watanabe, T. (2017), "The impact of project organizational culture on the performance of construction projects", Sustainability, Vol. 9 No. 5, p. 781, doi: 10.3390/su9050781.

Ostroff, C., Kinicki, A.J. and Muhammad, R.S. (2012), "Organizational culture and climate", Handbook of Psychology, 2nd ed., John Wiley and Sons, Hoboken, New Jersey. doi: 10.1002/9781118133880. hop212024.

Pinto, J.K. and Slevin, D.P. (1987), "Critical factors in successful project implementation", IEEE Transactions on Engineering Management, Vols EM-34 No. 1, pp. 22-27, doi: 10.1109/TEM.1987. 6498856.

Piwowar-Sulej, K. (2014), "Kultura organizacyjna i jej wpływ na działalność projektową - studium przypadku”, Marketing i Rynek, Vol. 5, pp. 143-148, doi: 10.13140/2.1.1346.1769.

Piwowar-Sulej, K. (2016), "Kultura organizacyjna jako determinanta sukcesu organizacji zorientowanych na projekty - optyka specjalistów HR”, Zarzadzanie i Finanse, Vol. 2 No. 2, pp. 275-284.

Piwowar-Sulej, K. (2020), "Types of organizational culture in the context of project management methodologies", in Soliman Khalid, S. (Ed.), Education Excellence and Innovation Management: A 2025 Vision to Sustain Economic Development during Global Challenges, International Business Information Management Association (IBIMA), Sevilla.

Piwowar-Sulej, K. (2021), "Core functions of sustainable human resource management. A hybrid literature review with the use of H-classics methodology", Sustainable Development, sd.2166, doi: 10.1002/sd.2166.

Rowlinson, S. and Root, D. (1996), "The impact of culture on project management", available at: https:/www.researchgate.net/publication/305397606.

San Cristóbal, J.R., Carral, R., Diaz, E., Fraguela, J.A. and Iglesias, G. (2018), “Complexity and project management, a general overview", Complexity, Vol. 2018, pp. 1-10, doi: 10.1155/2018/4891286.

Saynisch, M. (2010), "Beyond frontiers of traditional project management: an approach to evolutionary, self-organizational principles and the complexity theory - results of the research program”, Project Management Journal, Vol. 41 No. 2, pp. 21-37, doi: 10.1002/ pmj.20159.

Schein, E.H. (1990), “Organizational culture”, American Psychologist, Vol. 45 No. 2, pp. 109-119, doi: 10. 1037/0003-066X.45.2.109.

Schwaber, K. and Sutherland, J. (2017), "The scrum guide, the definitive guide to scrum: the rules of the game", available at: https://www.scrumguides.org/docs/scrumguide/v2017/2017-ScrumGuide-US.pdf.

Shore, B. and Cross, B.J. (2005), "Exploring the role of national culture in the management of largescale international science projects", International Journal of Project Management, Vol. 23 No. 1, pp. 55-64, doi: 10.1016/j.ijproman.2004.05.009.

Silva, M.D.C. and Gomes, C.F.S. (2015), "Practices in project management according to Charles Handy's organizational culture typologies", Procedia Computer Science, Vol. 55, pp. 678-687, doi: 10.1016/j.procs.2015.07.074.

Špundak, M. (2014), "Mixed agile/traditional project management methodology - reality or illusion?", Procedia - Social and Behavioral Sciences, Vol. 119, pp. 939-948, doi: 10.1016/j.sbspro.2014.03.105.

Stankevičiūtè, Ž. and Savanevičienè, A. (2019), "Can sustainable HRM reduce work-related stress, work-family conflict, and burnout?", International Studies of Management and Organization, Routledge, Vol. 49, No. 1, pp. 79-98, doi: 10.1080/00208825.2019.1565095. 
Stare, A. (2014), "Agile project management in product development projects", Procedia - Social and Behavioral Sciences, Vol. 119, pp. 295-304, doi: 10.1016/j.sbspro.2014.03.034.

Statistics Poland (2019), Specialized Segments of Financial Market 2018, Central Statistical Office, Warsaw.

Thakor, A.V. (2015), "Corporate culture in banking”, SSRN Electronic Journal. doi: 10.2139/ssrn. 2565514.

Thomas, G. and Fernández, W. (2008), “Success in IT projects: a matter of definition?”, International Journal of Project Management, Vol. 26 No. 7, pp. 733-742, doi: 10.1016/j.ijproman.2008.06.003.

Titov, E. and Umarova, L. (2017), "Impact of real and propagated values on organisational success", Congruence of Personal and Organizational Values, InTech. doi: 10.5772/intechopen.69460.

Turner, R.J. (1993), The Handbook of Project-Based Management - Improving the Processes for Achieving Strategic Objectives, MCGraw-Hill, London.

Vlahov, R.D., Mišić, S. and Radujković, M. (2016), "The influence of cultural diversity on project management competence development - the Mediterranean experience", Procedia - Social and Behavioral Sciences, Vol. 226, pp. 463-469, doi: 10.1016/j.sbspro.2016.06.212.

Ward, L.J. (2000), Dictionary of Project Management Terms, ESI International, Darlington Virginia.

Webster, E. and Jensen, P.H. (2006), "Investment in intangible capital: an enterprise perspective*”, The Economic Record, Vol. 82 No. 256, pp. 82-96, doi: 10.1111/j.1475-4932.2006.00296.x.

Wiewióra, A., Murphy, G.D., Trigunarsyah, B. and Coffey, V. (2012), "Uncovering the impact of organisational culture types on the willingness to share knowledge between projects", in Williams, J. (Ed.), Proceedings of the PMI Research and Education Conference 2012, Project Management Institute, pp. 1-16.

Wyrozębski, P., Juchniewicz, M. and Metelski, W. (2012), Wiedza, dojrzałość, ryzyko w zarzadzaniu projektami, Warsaw School of Economics, Warsaw.

Yazici, H.J. (2009), "The role of project management maturity and organizational culture in perceived performance", Project Management Journal, Vol. 40 No. 3, pp. 14-33, doi: 10.1002/pmj.20121.

\section{Corresponding author}

Katarzyna Piwowar-Sulej can be contacted at: katarzyna.piwowar-sulej@ue.wroc.pl

For instructions on how to order reprints of this article, please visit our website:

www.emeraldgrouppublishing.com/licensing/reprints.htm

Or contact us for further details: permissions@emeraldinsight.com 